\title{
The Effect of Service Recovery Strategies on Satisfaction with the Recovery: The Mediating Role of Distributive Justice
}

\author{
Gamal S. ALhawbani, Nadia A. M. Ali, and Abdel-Nasser M. Hammouda
}

\section{ABSTRACT}

The aim of this study was to test the effect of the Service Recovery Strategies
on the Satisfaction with the Recovery, as well as testing the effect of Service
Recovery Strategies on Distributive Justice. The study also aimed to identify
the effect of Distributive Justice on the Satisfaction with the Recovery, as
well as the test of the mediation role of Distributive Justice in the relationship
between Service Recovery Strategies and the Satisfaction with the Recovery.

The study was applied to a sample of (354) customers of the Internet companies in Egypt. Data analyzed using the SPSS program Data, as well as the AMOS program to test the quality of compatibility between data collected and theoretical data, and the Structural equation modeling to test the hypotheses of the study.

The results of the study showed that, there is a positive significant effect of some Service Recovery strategies and Distributive Justice on the Satisfaction with the Recovery. Also, there is a positive significant effect of some Service Recovery strategies on Distributive Justice. The study also found that the Distributive Justice mediated in the relationship between the Service Recovery Strategies and the Satisfaction with the Recovery. Based on these results was presented a set of recommendations, as well as suggest some future studies relevant to the subject of the study.

Keywords: Service Recovery strategies, Distributive Justice, Satisfaction with the Recovery.

\author{
Submitted : March 18, 2021 \\ Published : May 04, 2021 \\ ISSN: 2507-1076 \\ DOI: 10.24018/ejbmr.2021.6.3.819 \\ Gamal S. ALhawbani* \\ Hodeidah University, Republic of Yemen. \\ (e-mail: gsh200899@gmail.com) \\ Nadia A. M. Ali \\ Assiut University, Egypt. \\ (e-mail: nadia@aun.edu.eg) \\ Abdel-Nasser M. Hammouda \\ Assiut University, Egypt. \\ (e-mail: arwa@aun.edu.eg) \\ *Corresponding Author
}

\section{INTRODUCTION}

A service failure has become inevitable. Despite the efforts of service companies to prevent the failure, they find it difficult to prevent all failures [30]. Most of the service organizations failed to implement the zero-defect model despite its success in the field of the industry because of the nature of the service where the delivery of the most services require a high degree of human interactions between employees and customers, which increases the possibility of errors or defects in the service provision process [36]. Given the difficulty of preventing the service failure, service organizations have tended to use effective strategies to fix this failure and reduce its negative impact on customer behavior [20].

The service recovery is an important area of study, and in recent years many studies have been conducted to identify the most effective strategies for managing customer complaints and the service recovery [14]. A review of past studies concerned with the concept of service recovery shows that there is a complete agreement among these studies that the service recovery strategies take two forms: tangible and psychological strategies [32]. On the other hand, there is a difference between them about the degree of importance and effectiveness of these strategies. Some studies indicate that tangible strategies such as compensation and response speed have a greater impact than psychological strategies on customer satisfaction [10]. Other researchers focus on the importance of psychological strategies such as apologizing, explanation, listening, and empathy to the success of the recovery process [4]-[41].

Sometimes, organizations implement effective recovery strategies but that may not restore customer satisfaction [11], because customers are aware of the injustice of these strategies. Tsao [50] notes that the impact of service recovery strategies on customer satisfaction depends on their awareness of the justice of these strategies [50].

Distributive justice is one of the perceived justice dimensions that affect customer satisfaction with service recovery strategies. The concept of distributive justice refers to the end outcome of the service recovery process. In other words, did the tangible compensations (outputs) offer by the company offset the customer for the costs of the service failure [35]. There are differences among researchers about the effect of distributive justice on customer satisfaction, as some have emphasized the importance of distributive justice for increasing levels of customer satisfaction [34]-[46]. Unlike many researchers, Chebat \& Slusarczyk [8] stated that 
distributive justice is not essential predictor for the satisfaction with the recovery [8].

The Internet sector in Egypt is suffering from many problems and deficiencies that may lead to low levels of the customer satisfaction. Therefore, Internet companies must implement service recovery strategies efficiently and effectively to maintain customer satisfaction. Based on that, the current study is attempting to pursue research efforts concerned with the concept of service recovery. This study will focus on examining the mediating role of distributive justice in the relationship between service recovery strategies and the satisfaction with the recovery which applied on customers of Internet companies in Egypt.

\section{PRIOR LITERATURE AND HYPOTHESES}

\section{A. The Service Recovery Strategies and the Satisfaction with the Recovery}

The occurrence of service failure has clear negative effects on customer attitudes and behaviors especially when there is no quick response from the company to fix this failure [28]. In order for service providers to fix a failure, this requires that they have systems to identify, tracking and analyzing service failures help management identify common and recurring failure situations [21]. These systems enable the company to take action to prevent common failures, and to design appropriate strategies to fix unavoidable failures [40].

A review of previous studies concerned with the concept of service recovery shows that there is a clear difference between them about the strategies used to repair service failure. Smith et al. [47] model included four main strategies for service recovery namely: response speed, initiation, apology, and compensation [47]. Also, another study indicated that the service recovery needs to implement three strategies: compensation, apology, and response speed [3], while Harun et al. [18] focused on psychological strategies only, such as Explanation, response speed, apology, and empathy [18].

Corporate adoption of effective service recovery strategies not only contributes to the development of marketing communications programs but also acts as an effective tool for customer retention [2]. Most organizations encourage their employees to properly implement service recovery strategies because poor performance in service repair may multiply the problems instead of solving them, which increases the customer's dissatisfaction and increases his intention to stop dealing with the service provider [44]. Also, Jin et al. [22] study applied to a sample of (570) customers who use the Internet to purchase services in USA, concluded that high levels of performance in implementing service recovery strategies improve customer satisfaction and enhance their future behaviors [22].

In the same context, the Saputra \& Sunarti study applied to a sample of (115) customers for a service sector in Indonesia confirmed that providing strategies commensurate with the size and type of failure contribute to restoring customer satisfaction after repairing the service failure [45].

Based on the previous studies results the first hypothesis is of this study could be formulated as follows:
$\mathrm{H}_{1}$ : There is a positive effect of service recovery strategies (response speed, explanation, apology, and compensation) on the satisfaction with the recovery.

\section{B. The Service Recovery Strategies and Distributive Justice}

The concept of customers' evaluation of service recovery process from a cognitive perspective is termed perceived justice [15]. The concept of perceived justice provides an important framework for explaining customers' reactions to the company's handling of complaints related to service failure. It is also consistent with the service marketing literature which emphasizes the importance of effective communicating with customers during the service encounter [5].

The concept of distributive justice as a major dimension of perceived justice is derived from social exchange theory and equity theory, which emphasize the important role of perceived justice in a customers' evaluation of the exchange process [9]. Distributive justice refers to the final and tangible outcomes (output) of the service recovery process [26]. It also focuses on the customers' perception of the fairness of the tangible resources allocated by the firm to rectify and compensate for a service failure [35].

In the domain of service recovery, the concept of distributive justice is related to one of the most important service recovery strategies: the financial compensation strategy [25]. This is consistent with Smith et al. [47] which indicated that compensation positively effects on customers' perception of distributive justice [47]. This compensation is not limited to a financial loss, but extends to compensate the customer for lost time, anxiety, and effort resulting from service failure [28]. Compensating the customer for service failure increases his awareness of distributive justice and reduces his levels of anger and dissatisfaction. Also, it is increasing the strength of the relationship between customers and service providers [50].

Bradley \& Sparks [7] in their study applied on a sample of (461) customers of fast-food restaurants in Queensland, Australia found that the customers' evaluation of the fairness depends on the quality and efficiency of the service recovery strategies. The study showed that the quality of the explanation and the adequate financial compensation led to an increase the customer's awareness of the Justice of the service recovery process [7]. In the same context, some studies have examined the relationship between service recovery strategies and perceived justice. These studies concluded that there is a significant positive impact of implementing effective service recovery strategies on customers' perceptions of the fairness of the service recovery process [3], [18], [33].

Most of the results mentioned above have been accessed in foreign environments. So, the relationship between service recovery strategies and distributive justice needs to be tested in the Egyptian context. Based on the past literature the second hypothesis is of this study could be formulated as follows:

$\mathrm{H}_{2}$ : There is a positive effect of service recovery strategies (response speed, explanation, apology, and compensation) on distributive justice. 


\section{Distributive Justice and the Satisfaction with the Recovery}

The concept of customer satisfaction emerged as an inevitable result of the widespread adoption of the marketing concept. Maximizing customer satisfaction is the main focus of all efforts and strategies pursued by productive and service organizations [39]. Throughout the 1980s and the1990s, the concept of satisfaction has moved into the literature concerned with the service recovery process. This period witnessed a focus on customer reactions to service failure and their satisfaction with the service recovery strategies [43]. The failure of the service provider to fixes the defect negatively affects customer attitudes and behaviors, so the concept of customer satisfaction gains a lot of attention in the context of service recovery [23].

The model presented by Oliver \& Swan [38] was one of the first to the models of customer satisfaction in the context of service recovery. This model combined both perceived Justice, and expectation disconfirmation to test their impact on customer satisfaction. The model focused on one aspect of perceived justice, which is distributive justice [38]. The customer satisfaction with service recovery has been categorized into two types: satisfaction with the outputs of service recovery (end outcomes) and satisfaction with the service recovery process which refers to the customers' evaluation of the procedures and policies followed in the service repair [49].

Studies that examined the relationship between perceived justice and customer satisfaction in the field of service recovery relied on justice theory [42]. This theory indicates that the customers' evaluation of the service recovery process is based on their awareness of the fairness of the efforts and strategies followed by the firms to fix service failure. These studies indicated that there is a direct positive relationship between distributive justice and customer satisfaction with service recovery (e.g., [13], [27], [29], [37]).

In the same direction, Migacz et al. [31] study applied on a sample of (171) customers of airlines in the United States of America to identify the role of perceived justice in improving customer satisfaction. The results showed that all dimensions of perceived justice (distributive justice, interactional justice, and procedural justice) have a significant positive effect on customer satisfaction. This study also showed that the effect of distributive justice on customer satisfaction is greater than other dimensions [31]. The previous study agrees with the result of Muhammad [34] study applied to a sample of (453) of banking services sector customers in Pakistan. This study concluded that the increase of customer satisfaction levels after service recovery depends on their awareness of distributive justice [34]. Based on the previous studies results the third hypothesis is formulated as follows:

\section{$\mathrm{H}_{3}$ : There is a positive effect of distributive justice on the satisfaction with the recovery.}

\section{The mediation role of Distributive Justice}

Smith et al. [47] tested a model of service recovery process that includes several strategies Used by organizations for service recovery. The results indicate that these strategies positively effect on customers' perception of justice (distributive justice, interactional justice, and procedural justice), which in turn positively effect on customer satisfaction. This study also indicated that distributive justice is mediating the relationship between compensation strategy and the satisfaction with the recovery [47].

In the same context, a study was conducted of a sample of (312) graduate students at an American university to identify a nature of the relationship between service recovery strategies and customers' future intentions in the presence of perceived justice as a mediating variable. The results showed that the high levels of service recovery strategies increase justice Perceived, which in turn effect on future intentions [16]. The previous result is consistent with the Kwon [25] study, which indicated that the effect of compensation strategy on customer attitudes and behaviors depend on their awareness of the fairness of the tangible compensation received from the company [25]. Also, the study Bradley \& Sparks [7] emphasized that distributive justice plays a mediating role in the relationship between service recovery strategies and the satisfaction with the recovery.

It should be noted that the mediating role of distributive justice in the context of service recovery has not received much attention by researchers, especially in the Egyptian context, and therefore it needs more study and research. Based on the above, the fourth hypothesis of the study can be formulated as follows:

$\mathrm{H}_{4}$ : The distributive justice is mediating in the relationship between service recovery strategies (response speed, explanation, apology, and compensation) and the satisfaction with the recovery.

\section{STUDY METHODS}

\section{A. Study Model}

Based on the review of the previous literature and in order to realize the objectives of the current study, a model has been developed for the current study. The model shown in the Fig. 1 shows the relations between the Study variables as follows:

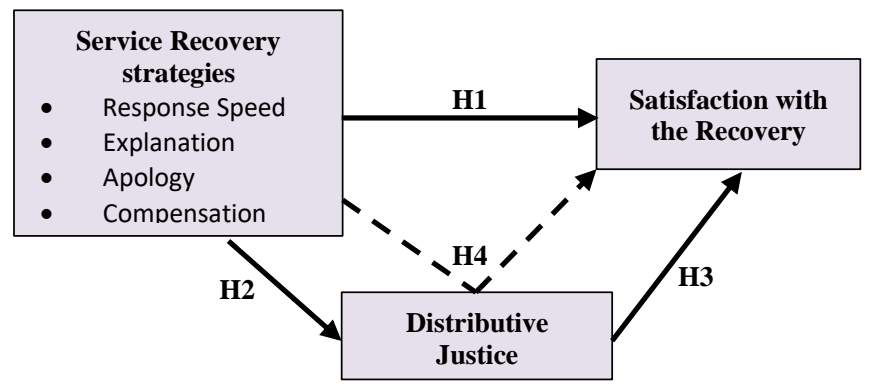

Fig. 1. The hypothesized model of the study.

\section{B. Study Population and Sample}

The study population consists of all customers of the internet companies in Egypt. The total number of users of the Internet service is (7.17) million. A sample of 400 customers has been selected. The returned questionnaires were 354 , with responses of $89 \%$.

Customers completed the questionnaire which includes their assessing of the service recovery strategies, distributive 
justice, and the satisfaction with the recovery. The questionnaire was translated into Arabic by the first author, and then the accuracy of the translation was checked by a professional translator.

\section{Measurement}

For the purposes of data collecting and testing of the study hypotheses, the questionnaire was prepared using the Likert scale of 5 degrees which range from [(5) strongly agree to (1) strongly disagree].

The service recovery strategies were measured through a scale of sixteen statements used by (Mostafa et al. [33]; Khashan [23]; Harun et al. [18]; Harrison-Walker [17]). This scale covers four strategies of service recovery: Response Speed (RSP), Explanation (EXN), Apology (APO) and Compensation (COM) (examples include: 1-Did not take long to solve the problem, 2-The company provided a convincing explanation for the reason of the problem, 3-The company apologized for the inconvenience the problem had brought to me, 4-The compensation the company provided me to cover my financial losses is good).

The second order confirmatory factor analysis of the scale was performed with an acceptable fit $(\mathrm{X} 2 / \mathrm{df}=1.362$, $\mathrm{CFI}=.972$, TLI=.965, RMSEA= .059). The Cronbach's Alpha for the scale is $(0.85)$.

This study used the scale of Ellyawati et al. [15] to measure the distributive justice (DSJ), which consists of four items. Examples of the scale items include: (Given the circumstances, I feel that the provider offered fair compensation). The confirmatory factor analysis of the scale was performed with an acceptable fit $(\mathrm{X} 2 / \mathrm{df}=1.583$, $\mathrm{CFI}=.975, \mathrm{TLI}=.951, \mathrm{RMSEA}=.067)$. The Cronbach's Alpha for the scale is (0.73).

The Satisfaction with the Recovery (SAR) was measured through a scale of six items used by Ellyawati et al. [15]. Examples of the scale items include: (I am satisfied with the way my problem was dealt with and resolved). The confirmatory factor analysis of the scale was performed with an acceptable fit $(\mathrm{X} 2 / \mathrm{df}=1.658, \mathrm{CFI}=.963$, TLI $=.954$, RMSEA= .062). The Cronbach's Alpha for the scale is $(0.84)$.

\section{Statistical Methods}

In the statistical analysis, the study used the Statistical Package for the Social Sciences (SPSS) program and Analysis of Moment Structures (AMOS). This study used the structural equation model: the confirmatory factor analysis to test the quality of the compatibility between the collected data and the theoretical data, and the structural model to test the study hypotheses. Sobel test was used to test the mediation effect of distributive justice [48].

\section{RESults}

\section{A. Descriptive Statistics}

Table I shows the correlation coefficients of study variables, means and standard deviation as follows:
TABLE I: MEANS, STANDARD DEVIATIONS AND CORRELATION COEFFICIENTS

\begin{tabular}{ccccccccc}
\hline \hline Variables & Mean & $\begin{array}{c}\text { Standard } \\
\text { Deviation }\end{array}$ & RSP & EXN & APO & COM & DSJ & SAR \\
\hline \hline RSP & 2.98 & 0.76 & $(0.81)$ & & & & & \\
EXN & 3.09 & 0.86 & ${ }^{* *} 0.64$ & $(0.85)$ & & & & \\
APO & 3.15 & 0.89 & ${ }^{* *} 0.55$ & ${ }^{* *} 0.62$ & $(0.88)$ & & & \\
COM & 2.13 & 0.93 & ${ }^{* *} 0.40^{* *} 0.41^{* *} 0.38$ & $(0.79)$ & & \\
DSJ & 2.36 & 0.75 & ${ }^{* *} 0.48^{* *} 0.41^{* *} 0.42^{* *} 0.65$ & $(0.73)$ & \\
SAR & 2.84 & 0.82 & ${ }^{* *} 0.59$ & ${ }^{* *} 0.57$ & $0.49^{* *} 0.64$ & ${ }^{* *} 0.72$ & $(0.84)$ \\
\hline \hline
\end{tabular}

$* *$ correlation is significant at 0.01 .

Cronbach's Alpha is shown between brackets.

Table I shows the following: the correlation coefficients show that Service Recovery Strategies (Response Speed (RSP), Explanation (EXN), Apology (APO) and Compensation (COM) are positively correlated with the distributive justice (DSJ) and positively correlated with the Satisfaction with the Recovery (SAR). The distributive justice (DSJ) is positively correlated with Satisfaction with the Recovery (SAR). All these correlation coefficients are significant at 0.01 .

\section{B. Hypotheses Testing}

The following the Fig. 2 shows the structural model of the study:

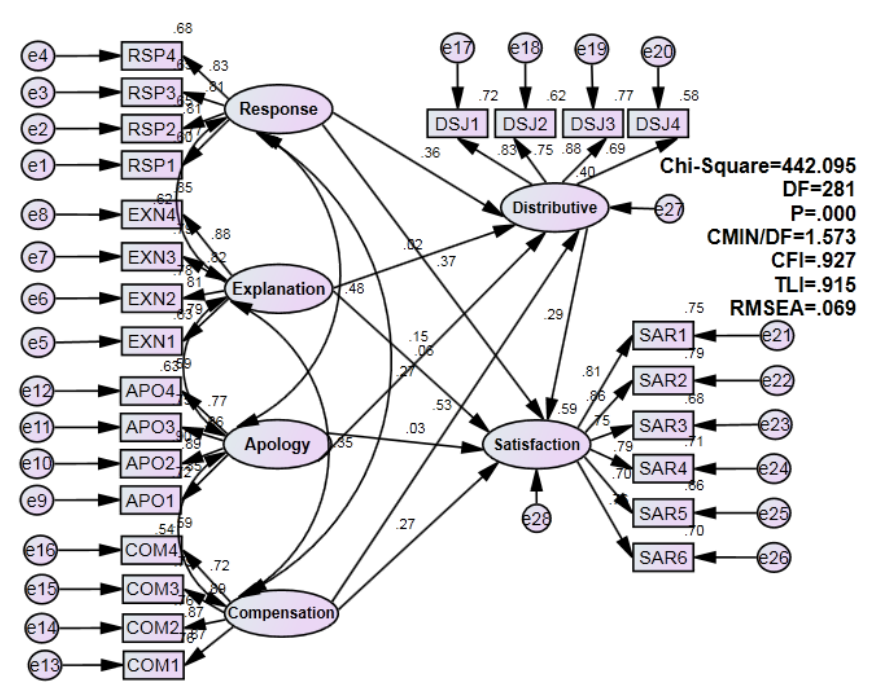

Fig. 2. The structural model of the study.

Table II shows direct and indirect effect between the study variables.

The results of Table II show the following.

The first hypothesis of the study indicates there is a direct positive effect of the service recovery strategies (response speed, explanation, apology, and compensation) on the satisfaction with the recovery. The results partially support this hypothesis, where we Note from the results of Table II there is a direct positive effect of response speed on the satisfaction with the recovery $(\beta=0.365$, and $\mathrm{T}=5.637$, and $\mathrm{P}=0.000)$, and there is a direct positive effect of compensation on the satisfaction with the recovery $(\beta=$ $0.271, \mathrm{~T}=4.865$, and $\mathrm{P}=0.002$ ). This means that the higher the response speed and compensation, the higher the satisfaction with the recovery. Also, the results showed that was no significant direct effect of explanation and apology on the satisfaction with the recovery. So, the first hypothesis is 
partially accepted.

TABLE II: RESULTS OF DIRECT AND INDIRECT EFFECTS BETWEEN STUDY VARIABLES

\begin{tabular}{|c|c|c|c|c|c|}
\hline & Paths & Direct effect & $\begin{array}{c}\text { Indirect } \\
\text { effect }\end{array}$ & $\begin{array}{c}\text { Total } \\
\text { effects }\end{array}$ & \\
\hline RSP & $\rightarrow$ SAR & 0.365 & 0.104 & 0.469 & \\
\hline EXN & $\rightarrow$ SAR & 0.056 & 0.006 & 0.062 & \\
\hline APO & $\rightarrow$ SAR & 0.031 & 0.029 & 0.060 & \\
\hline $\mathrm{COM}$ & $\longrightarrow$ SAR & 0.271 & 0.152 & 0.423 & \\
\hline \multicolumn{2}{|c|}{ Value of paths } & $\begin{array}{c}\text { Standard } \\
\text { Coefficient }(\beta)\end{array}$ & $\begin{array}{c}\text { Standard } \\
\text { Error }\end{array}$ & $\begin{array}{c}\text { CR value } \\
\text { (T) }\end{array}$ & $\mathrm{P}$ \\
\hline RSP & $\rightarrow$ SAR & 0.365 & 0.063 & 5.637 & 0.000 \\
\hline EXN & $\rightarrow$ SAR & 0.056 & 0.054 & 1.192 & 0.609 \\
\hline APO & $\rightarrow \mathrm{SAR}$ & 0.031 & 0.071 & 0.492 & 0.744 \\
\hline $\mathrm{COM}$ & $\rightarrow$ SAR & 0.271 & 0.052 & 4.865 & 0.002 \\
\hline RSP & $\rightarrow \mathrm{DSJ}$ & 0.362 & 0.062 & 5.743 & 0.000 \\
\hline EXN & $\longrightarrow \mathrm{DSJ}$ & 0.015 & 0.079 & 0.236 & 0.672 \\
\hline APO & $\longrightarrow \mathrm{DSJ}$ & 0.146 & 0.076 & 2.375 & 0.044 \\
\hline $\mathrm{COM}$ & $\longrightarrow$ DSJ & 0.529 & 0.065 & 7. 952 & 0.000 \\
\hline DSJ & $\rightarrow$ SAR & 0.287 & 0.051 & 5.465 & 0.000 \\
\hline
\end{tabular}

The second hypothesis states that there is a direct positive effect of the service recovery strategies (response speed, explanation, apology, and compensation) on the distributive justice. The results partially support this hypothesis where the results showed that there is a direct positive effect of response speed on the distributive justice $(\beta=0.362, \mathrm{~T}=5.743$, and $\mathrm{P}=0.000)$, and there is a direct positive effect of apology on the distributive justice $(\beta=0.146, \mathrm{~T}=2.375$, and $\mathrm{P}=0.044)$, and there is a direct positive effect of compensation on the distributive justice $(\beta=0.529, \mathrm{~T}=7.952$, and $\mathrm{P}=0.000)$. This means that the higher the response speed, apology, and compensation, the higher the Customer perception of distributive justice. Also, the results showed that was no significant direct effect of explanation on the distributive justice. So, the second hypothesis is partially accepted.

The third hypothesis indicates that there is a direct positive effect of the distributive justice on the satisfaction with the recovery. The results showed that there is a direct positive effect of the distributive justice on the satisfaction with the recovery $(\beta=0.287, T=5.465$ and $P=0.000)$. This means that the higher the distributive justice, the higher the satisfaction with the recovery. So, the third hypothesis is accepted.

The fourth hypothesis states that the distributive justice mediates the relationship between the service recovery strategies (response speed, explanation, apology, and compensation) and the satisfaction with the recovery. The results partially support this hypothesis, where We Note from the results of Table II that there is an indirect positive effect of response speed on the satisfaction with the recovery $(\beta=$ $0.104)$, and there is an indirect positive effect of compensation on the satisfaction with the recovery $(\beta=$ 0.152). Also, the results showed that was no significant indirect effect of explanation and apology on the satisfaction with the recovery. So, the fourth hypothesis is partially accepted.

To confirm these results, Sobel test was used. The mediation role of the distributive justice is achieved when the estimated estimates are not less than 0.08 and the value $(\mathrm{P})$ is significant. The weighted estimates of the result are equal to the multiplying the value of the first path (independent and mediator) by the second path (mediator and dependent). This result is reflected in Table III obtained from the Sobel Test.

The standard estimates reached $(0.362 \times 0.287)=0.104$, the value of $\mathrm{T}=4.052$ and $\mathrm{P}=0.000$ ), thus the distributive justice mediates the relationship between the response speed and the satisfaction with the recovery. Also, the standard estimates reached $(0.529 \times 0.287)=0.152$, the value of $\mathrm{T}=$ 4.628 and $\mathrm{P}=0.000)$, thus the distributive justice mediates the relationship between the compensation and the satisfaction with the recovery.

TABLE III: SOBEL TEST RESULTS FOR THE INDIRECT EFFECTS OF Distributive Justice AS A MEDIATING VARIABLE

\begin{tabular}{ccccccc}
\hline \hline Exogenous & Endogenous & Mediation & Estimate & S.E. & C. R & P \\
\hline RSP & SAR & DSJ & 0.104 & 0.026 & 4.052 & 0.000 \\
EXN & SAR & DSJ & 0.006 & 0.024 & 0.190 & 0.849 \\
APO & SAR & DSJ & 0.029 & 0.023 & 1.818 & 0.070 \\
COM & SAR & DSJ & 0.152 & 0.032 & 4.628 & 0.000 \\
\hline
\end{tabular}

\section{DISCUSSION}

The aim of this study was to test the effect of the service recovery strategies on the satisfaction with the recovery, as well as testing the effect of service recovery strategies on distributive justice. The study also aimed to identify the effect of distributive justice on the satisfaction with the recovery, as well as the test of the mediation role of distributive justice in the relationship between service recovery strategies and the satisfaction with the recovery for Internet company customers in Egypt.

The results partially supported the first hypothesis, which proved a significant positive effect of some service recovery strategies (response speed and compensation) on the satisfaction with the recovery. On the other side, the results showed that was no significant direct effect of explanation and apology on the satisfaction with the recovery. This result is logical because it is natural for customers to be more interested in the final outputs of the service recovery process represented in the speed in repairing service and tangible compensation than they are concerned with psychological aspects such as apology and explanation.

This result can be interpreted by that the presence of a quick response from service providers to contain the problem of internet service failure, fix the defect in a timely, and to provide of the tangible compensation to the customer for compensate him for the loss caused by the failure of the service such as: a reduction in the monthly subscription fee for a specific period of time, or doubling the size of the subscription with the same current fees For a specific period, or any other financial or tangible compensations, Which contributes to restoring customer satisfaction. This result is consistent with the results of previous studies [1], [12], [19], [51] regarding the positive significant effect of both response speed and compensation on the satisfaction with the recovery.

The results of the study also partially supported the second hypothesis, which proved a significant positive effect of some service recovery strategies (response speed, apology, and compensation) on distributive justice. The results also showed that the compensation is the strategy most influencing on customers' perception of distributive justice. This result is consistent with the results of past studies [3], 
[18], [33]. This result is logical because distributive justice is related to the customer's perception of the fairness of the service recovery outcomes represented in solving a problem, fixing of service failure, and providing tangible compensation to the customer for the loss resulting from this failure. Therefore, it is natural that the customer's obtaining the appropriate tangible compensation increases his perception of distributive justice.

As for the significant positive effect of both response speed and apology on the distributive justice, this result can be interpreted that the customer's obtaining a fair financial compensation is not sufficient to create a high awareness of distributive justice. But enhancing the customer's perception of distributive justice for the service recovery process also requires the company to fix the defect as quickly as possible (response speed), and to provide an appropriate apology to the customer.

The results also supported the third hypothesis, which showed a significant positive effect of distributive justice on the satisfaction with the recovery. This result is consistent with the results of past studies [24], [29], [37]. This result is also consistent with the justice theory which indicates that customers' evaluation of service recovery strategies is based on their awareness of the fairness of the efforts, procedures and final outputs provided by the company to repair the service and compensate them for the loss resulting from service failure, which in turn positively affects their satisfaction. The previous result can be interpreted by the fact that the customer's perception of the fairness of the final outcomes of the service recovery (distributive justice) represented in repairing service failure and obtaining a just compensation from the company leads to higher levels of customer satisfaction.

The results of the study also partially supported the fourth hypothesis, where the study proved the mediating role of distributive justice in the relationship between some service recovery strategies (response speed and compensation) and satisfaction with the recovery. On the other hand, distributive justice did not play the mediating role in the relationship between apology, interpretation, and satisfaction with the recovery. This result is consistent with the results of previous studies [7], [16], [47]. Based on the above mentioned result, we can say that increasing the customer's awareness of distributive justice contributes to increasing the positive impact of service recovery strategies on satisfaction with the recovery. In other words, if the customer realizes that the service recovery strategies (response speed and compensation) are fair, they will be more satisfied with the recovery process as a whole.

\section{MANAGERIAL IMPLICATIONS}

The result of the current study indicates the necessity for Internet companies to adopt the concept of service recovery and use it as a basic means to solve the problems associated with providing the service, and to take all measures that help to properly implement recovery strategies to ensure that they achieve the desired effect. This can be achieved through the following:

- Designing an effective system to detect, track and analyze service failures, identify their causes, and then identify the failures that can be avoided in an attempt to prevent their occurrence in the future, as well as seek to recovery from the negative effects of unavoidable failures.

- Selecting and designing service recovery strategies in an orderly manner and implementing them according to a predetermined plan by taking flexible measures that allow employees to adapt those strategies according to circumstances of each service encounter.

- Providing clear and specific instructions (written and oral) to help front-line staff in implementing the service recovery process and selecting recovery strategies commensurate with the size and type of each failure.

- Follow-up and continuous evaluation of the effectiveness and efficiency of service recovery strategies and their compatibility with customer expectations and adapting those strategies to match the continuous changes in the marketing environment.

The results of this study also indicate that customers' perception of distributive justice during evaluating the service recovery process contributes to achieving high levels of satisfaction. Therefore, Internet companies must strive to create a perception among their customers about the fairness of the final outcomes of the recovery process by increasing interest in tangible strategies to fix service failures. This can be achieved through the following:

- Allocating appropriate financial budgets for the service recovery process that enables the provision of tangible compensations to compensate the customer for the financial and psychological losses resulting from the failure of the service, which in turn contributes to creating a high awareness for him of distributive justice. Tangible compensations include a reduction in the monthly subscription fee for a specific period of time or doubling the size of the subscription with the same current fees for a specific period or add extra advantage and services for free.

- Providing training programs for front-line staff based on simulation of real-life problems that help to give them all skills and experiences to enable them to provide quick reactions to fix service failure in a short period of time.

\section{LIMITATIONS AND FUTURE RESEARCH}

The current study was applied to the Internet sector in Egypt, so there is a difficulty of generalizing the results to other sectors or to the same sector in other countries because of the different cultures among countries [50]. Therefore, the proposed model in the current study can be tested to ascertaining its validity in different cultural and application environments.

In this study, Service recovery was measured by four strategies. On the other hand, other researchers studied the relationship between the service recovery and customer satisfaction using six strategies [6]. Consequently, results may differ in the case of examining the effect of other service recovery strategies on customer satisfaction.

The present study examined the effect of one type of perceived justice (distributive justice) on customer satisfaction. However, customer satisfaction is affected by other types of perceived justice. So, there is a need to study 
other dimensions of perceived justice that may directly or indirectly affect the relationship between service recovery strategies and customer satisfaction such as procedural justice, interactional justice, and informational justice.

This study found that there was no significant effect of psychological strategies such as explanation and apology on customer satisfaction with service recovery. Future studies must therefore be directed to test these relationships for validation.

\section{CONCLUSION}

The results of the current study confirmed that there was a positive effect of some service recovery strategies (response speed and compensation) and distributive justice on satisfaction with the recovery. This leads us to the fact that if organizations want to maintain customer satisfaction after service failure, they must quickly fix the service failure and provide tangible compensation to compensate the customer for the loss resulting from this failure, and then create a high perception among customers of the fairness of the service recovery outcomes.

The findings also indicated that psychological strategies such as apology and explanation for the service recovery had no significant impact on customer satisfaction. This explains why customer satisfaction levels are low even though Internet companies in Egypt use psychological strategies for the service recovery. Therefore, companies must pay greater attention to tangible recovery strategies.

This study found a positive effect of service recovery strategies on the customer's evaluation of the fairness of that recovery (perceived justice). Based on this, we conclude that the customer's perception of the fairness of the service recovery process depends mainly on the efficiency and effectiveness of the strategies implemented by Internet companies to fix service failure.

The study emphasized the mediating role of distributive justice in the relationship between some service recovery strategies and satisfaction with the recovery. This indicates that customers' perception of distributive justice plays an important role in enhancing the positive impact of the service recovery strategies on satisfaction with the recovery.

\section{REFERENCES}

[1] Albrecht, A. K., Schaefers, T., Walsh, G., \& Beatty, S. E. "The effect of compensation size on recovery satisfaction after group service failures: the role of group versus individual service recovery," Journal of Service Research, Vol. 22, No. 1, PP. 60-74, 2019.

[2] Azemi, Y., \& Ozuem, W. "Online service failure: understanding the building blocks of effective recovery strategy," in Leveraging Computer-Mediated Marketing Environments, IGI Global, 2019, Ch. 12, PP. 249-264.

[3] Bakar, S. Z. A. "Service Recovery in E-Services: Service Recovery Process, Perceived Justice and Satisfaction," Unpublished Ph.D. dissertation, Graduate School, Southern Illinois Univ., Carbondale, U.S., 2017.

[4] Bian, X., Chen, T., Ma, K., Zheng, C., \& Devlin, J. "Is high recovery more effective than expected recovery in addressing service failure?: A moral judgment perspective," Journal of Business Research, Vol. 82, PP. 1-9, 2018.

[5] Blodgett, J. G., Hill, D. J., \& Tax, S. S. "The effects of distributive, procedural, and interactional justice on postcomplaint behavior,' Journal of Retailing, Vol. 73, No. 2, PP. 185-210, 1997.
[6] Boshoff, C. "RECOVSAT: An instrument to measure satisfaction with transaction-specific service recovery," Journal of Service Research, Vol. 1, No. 3, PP. 236-249, 1999.

[7] Bradley, G., \& Sparks, B. "Explanations: if, when, and how they aid service recovery," Journal of Services Marketing, Vol. 26, No. 1, PP. 41-51, 2012.

[8] Chebat, J. C., \& Slusarczyk, W. "How emotions mediate the effects of perceived justice on loyalty in service recovery situations: an empirical study," Journal of Business Research, Vol. 58, No. 5, PP. 664-673, 2005.

[9] Chetta, M. H. "Impact of Loyalty Program Membership on Satisfaction, Loyalty Intentions, and Word-of-Mouth Intentions Following a Service Failure," Unpublished Ph.D. dissertation, Hofstra Univ., Hempstead, New York., U.S., 2014.

[10] Chuang, S. C., Cheng, Y. H., Chang, C. J., \& Yang, S. W. "The effect of service failure types and service recovery on customer satisfaction: a mental accounting perspective," The Service Industries Journal, Vol. 32, No. 2, PP. 257-271, 2012.

[11] Craighead, C. W., Karwan, K. R., \& Miller, J. L. "The effects of severity of failure and customer loyalty on service recovery strategies," Production and Operations Management, Vol. 13, No. 4, PP. 307-321, 2004.

[12] Crisafulli, B., \& Singh, J. "Service failures in e-retailing: Examining the effects of response time, compensation, and service criticality," Computers in Human Behavior, Vol. 77, PP. 413-424, 2017.

[13] Del Río-Lanza, A. B., Vázquez-Casielles, R., \& Díaz-Martín, A. M. "Satisfaction with service recovery: Perceived justice and emotional responses," Journal of Business Research, Vol. 62, No. 8, PP. 775-781, 2013.

[14] DeWitt, T., \& Brady, M. K. "Rethinking service recovery strategies: the effect of rapport on consumer responses to service failure," Journal of Service Research, Vol. 6, No. 2, PP. 193-207, 2003.

[15] Ellyawati, J., Purwanto, B. M., \& Dharmmesta, B. S. "The effect of perceived justice on customer satisfaction in the service recovery context: testing mediating variables," Journal of Service Science, Vol. 5, No. 2, PP. 87-100, 2012.

[16] Ha, J., \& Jang, S. S. "Perceived justice in service recovery and behavioral intentions: The role of relationship quality," International Journal of Hospitality Management, Vol. 28, No. 3, PP. 319-327, 2009.

[17] Harrison-Walker, L. J. "The critical role of customer forgiveness in successful service recovery," Journal of Business Research, Vol. 95, PP. 376-391, 2019.

[18] Harun, A., Rokonuzzaman, M., Prybutok, G., \& Prybutok, V. R. "How to influence consumer mindset: A perspective from service recovery," Journal of Retailing and Consumer Services, Vol. 42, PP. 65-77, 2018.

[19] Hocutt, M. A., Bowers, M. R., \& Todd Donavan, D. "The art of service recovery: fact or fiction?," Journal of Services Marketing, Vol. 20, No. 3, PP. 199-207, 2006.

[20] Hoffman, K. D., \& Bateson, J. E. Services marketing: concepts, strategies, \& cases, 4st ed., U.S.: South-Western, Cengage Learning, 2010.

[21] Hoffman, K. D., Kelley, S. W., \& Rotalsky, H. M. "Tracking service failures and employee recovery efforts," Journal of Services Marketing, Vol. 9, No. 2, PP. 49-61, 1995.

[22] Jin, D., DiPietro, R. B., \& Fan, A. "The impact of customer controllability and service recovery type on customer satisfaction and consequent behavior intentions," Journal of Hospitality Marketing \& Management, Vol. 29, No. 1, PP. 65-87, 2020.

[23] Khashan, M. A. "A Proposed Framework for the Relationship between Service Recovery and Customer Loyalty -Applied to Internet service customers in Dakahliya governorate," Unpublished Ph.D. dissertation, Faculty of Commerce, Mansoura Univ., Egypt, 2018.

[24] Kuo, Y. F., \& Wu, C. M. "Satisfaction and post-purchase intentions with service recovery of online shopping websites: Perspectives on perceived justice and emotions," International Journal of Information Management, Vol. 32, No. 2, PP. 127-138, 2012.

[25] Kwon, S. "Effectiveness of compensation depending on relationship level: The mediating role of perceived equity," Unpublished M.S. thesis, Graduate School, Purdue Univ., West Lafayette, Indiana, U.S., 2010.

[26] Lin, H. H., Wang, Y. S., \& Chang, L. K. "Consumer responses to online retailer's service recovery after a service failure: perspective of justice theory," Managing Service Quality: An International Journal, Vol. 21, No. 5, PP. 511-534, 2011.

[27] Lopes, E. L., \& Da Silva, M. A. "The effect of justice in the history of loyalty: A study in failure recovery in the retail context," Journal of Retailing and Consumer Services, Vol. 24, PP. 110-120, 2015.

[28] Lovelock, C., \& Wirtz, J. Services Marketing: People, Technology, Strategy. 7st ed., New Jersey, U.S.: Prentice Hall, Pearson, 2014. 
[29] Marimuthu, M., Nikbin, D., Hyun, S. S., \& Ismail, I. "Relationships of perceived justice to service recovery, service failure attributions, recovery satisfaction, and loyalty in the context of airline travelers," Asia Pacific Journal of Tourism Research, Vol. 20, No. 3, PP. 239-262, 2015.

[30] Maxham III, J. G. "Service recovery's influence on consumer satisfaction, positive word-of-mouth, and purchase intentions," Journal of Business Research, Vol. 54, No. 1, PP. 11-24, 2001.

[31] Migacz, S. J., Zou, S., \& Petrick, J. F. "The "Terminal" Effects of Service Failure on Airlines: Examining Service Recovery with Justice Theory," Journal of Travel Research, Vol. 57, No. 1, PP. 83-98, 2018.

[32] Miller, J. L., Craighead, C., \& Karwan, K. "Service recovery: a framework and empirical investigation," Journal of Operations Management, Vol.18, No. 4, PP. 387- 400, 2000.

[33] Mostafa, R. B., Lages, C. R., Shabbir, H. A., \& Thwaites, D. "Corporate image: A service recovery perspective," Journal of Service Research, Vol. 18, No. 4, PP. 468-483, 2015.

[34] Muhammad, L. "Mediating role of customer forgiveness between perceived justice and satisfaction," Journal of Retailing and Consumer Services, Vol. 52, 101886, 2020.

[35] Nikbin, D., Armesh, H., Heydari, A., \& Jalalkamali, M. "The effects of perceived justice in service recovery on firm reputation and repurchase intention in airline industry," African Journal of Business Management, Vol. 5, No. 23, PP. 9814-9822, 2011.

[36] Nikbin, D., Ismail, I., Marimuthu, M., \& Salarzehi, H. "The relationship of service failure attributions, service recovery justice and recovery satisfaction in the context of airlines," Scandinavian Journal of Hospitality and Tourism, Vol. 12, No. 3, PP. 232-254, 2012.

[37] Nikbin, D., Hyun, S. S., Iranmanesh, M., Maghsoudi, A., \& Jeong, C. "Airline travelers' causal attribution of service failure and its impact on trust and loyalty formation: The moderating role of corporate social responsibility," Asia Pacific Journal of Tourism Research, Vol. 21, No. 4, PP. 355-374, 2015.

[38] Oliver, R. L., \& Swan, J. E. "Consumer perceptions of interpersonal equity and satisfaction in transactions: a field survey approach," Journal of Marketing, Vol. 53, No. 2, PP. 21-35, 1989.

[39] Oliver, R. L. "Whence consumer loyalty?," Journal of Marketing, Vol. 63, (Special Issue) PP. 33-44, 1999.

[40] Palmer, A. Principles of service marketing. Translated by Bahaa Shaheen, Alaa Ahmed, and Doaa Sharaqi, Cairo, Egypt: Arab Nile Group, 2009.

[41] Radu, A. G., Arli, D., Surachartkumtonkun, J., Weaven, S., \& Wright, O. "Empathy and apology: the effectiveness of recovery strategies," Marketing Intelligence \& Planning, Vol. 37, No. 4, PP. 358-371, 2019

[42] Rawls, J. A theory of justice. Revised ed., Cambridge, U.S.: Harvard Univ. Press, 1971.

[43] Riscinto-Kozub, K. "The effects of service recovery satisfaction on customer loyalty and future behavioral intentions: An exploratory study in the luxury hotel industry," Unpublished Ph.D. dissertation, Graduate Faculty, Auburn Univ., U.S.,2008.

[44] Sabharwal, N., \& Soch, H. "Confirmatory factor analysis of determinants of service recovery," Global Business Review, Vol. 12, No. 2, PP. 297-318, 2011.

[45] Saputra, N. D., \& Sunarti, S. "Pengaruh Service Recovery Terhadap Kepuasan Pelanggan (Survei pada Pelanggan PDAM Kota Malang)," Jurnal Administrasi Bisnis, Vol. 78, No. 1, PP. 150-155, 2020.

[46] Sengupta, S. "How Does Culture Impact Customer Evaluation in Online Complaining?: Evidence from Germany and India," Journal of Global Information Management (JGIM), Vol. 28, No. 2, PP. 131-159, 2020.

[47] Smith, A. K., Bolton, R. N., \& Wagner, J. "A model of customer satisfaction with service encounters involving failure and recovery," Journal of Marketing Research, Vol. 36, No. 3, PP. 356-372, 1999.

[48] Sobel, M. E. "Asymptotic confidence intervals for indirect effects in structural equation models," Sociological Methodology, Vol. 13, PP. 290-312, 1982.

[49] Stauss, B. "The dimensions of complaint satisfaction: process and outcome complaint satisfaction versus cold fact and warm act complaint satisfaction," Managing Service Quality: An International Journal, Vol. 12, No. 3, PP. 173-183, 2002.

[50] Tsao, W. C. "Star power: the effect of star rating on service recovery in the hotel industry," International Journal of Contemporary Hospitality Management, Vol. 30, No. 2, PP. 1092-1111, 2018.

[51] Varela-Neira, C., Vázquez-Casielles, R., \& Iglesias, V. "The effects of customer age and recovery strategies in a service failure setting," Journal of Financial Services Marketing, Vol. 15, No. 1, PP. 32-48, 2010.

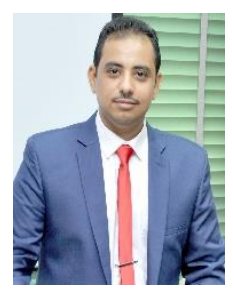

Gamal S. ALhawbani was born in Hodeidah, Republic of Yemen in the twenty-second of January 1983. He has been graduated from Hodeidah University in June 2007. He has been awarded the MSc in Business Administration in November 2016 and the $\mathrm{PhD}$. in Business Administration (Business Administration and Marketing) in 2021 from Assiut University, Egypt.

Dr. ALhawbani published some research papers in local conferences and journals. His research interests include service recovery, empowerment and perceived justice, corporate social responsibility, Mental Image Management, and behavioral intentions.

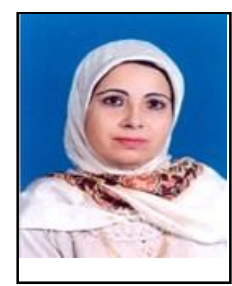

Nadia A. M. Ali was born in Qena, Egypt on the 21st of March 1955. She has been graduated from Assiut University in June 1977. She has been awarded the MSc in Business Administration in 1984 and the PhD. in Business Administration (HRM) in 1998. She completed her $\mathrm{PhD}$. research work at Assiut University, Egypt. She has been promoted as an associate professor of Business Administration in September 2005 and as a professor of HRM in 2015 She was acting as the chairman of Business Administration Department, Faculty of Economics and Administration, University of October 6, 2006/2007, and the chairman of Business Administration Department in Assiut University in 2007-2015. Currently, she is acting as Member of the Commercial Studies Sector Committee of the Supreme Council of Universities in Egypt.

Prof. Nadia A. M. Ali published more than 20 research papers in local, regional, and international journals. Her research interests include leadership, Selection and appointment, training, career path, organizational justice, deviant work behaviors (e.g., Bullying, counterproductive work behaviors, and violence at work).

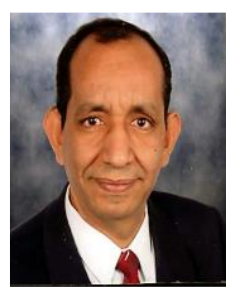

Prof Abdel-nasser M. Hammouda was born in Assiut, Egypt in the fifth of May 1954. He has been graduated from Assiut University in May 1976. He has been awarded the MSc in Business Administration in 1983 and the PhD. in Industrial Management in 1990 from University of Pennsylvania, U.S. He completed her $\mathrm{PhD}$. research work at Assiut University, Egypt. He has been promoted as an associate professor of Business Administration in 1996 and as a professor of Business Administration and HRM in 2005. He was acting as the Vice Dean for Education and Student Affairs in Faculty of Commerce - Assiut University in 2006. He was acting as the Dean of the Faculty of Commerce, Assiut University in 2012.

Prof. Hammouda published more than 20 research papers in local, regional, and international journals. His research interests include organizational behavior, organizational commitment and work motivation, effective teamwork approach, job security, job satisfaction, selection, appointment, and globalization of the human resource. 